\title{
Redox Report
}

\section{Evaluation of oxidative stress markers in neonates with intra-uterine growth retardation}

\section{Zsuzsanna Hracsko, Hajnalka Orvos, Zoltan Novak, Attila Pal \& Ilona S. Varga}

To cite this article: Zsuzsanna Hracsko, Hajnalka Orvos, Zoltan Novak, Attila Pal \& llona S. Varga (2008) Evaluation of oxidative stress markers in neonates with intra-uterine growth retardation, Redox Report, 13:1, 11-16, DOI: 10.1179/135100008X259097

To link to this article: https://doi.org/10.1179/135100008X259097

册Published online: 02 Dec 2013.

Submit your article to this journal $\pi$

Џ Article views: 33

Q View related articles ¿

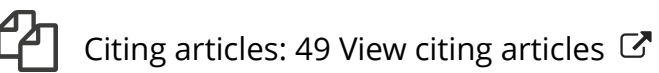




\title{
Research article
}

\section{Evaluation of oxidative stress markers in neonates with intra-uterine growth retardation}

\author{
Zsuzsanna Hracsko ${ }^{1}$, Hajnalka Orvos ${ }^{2}$, Zoltan Novak $^{3}$, Attila Pal ${ }^{2}$, Ilona S. Varga ${ }^{1}$ \\ ${ }^{I}$ Department of Biochemistry and Molecular Biology, Faculty of Sciences, ${ }^{2}$ Department of Obstetrics and \\ Gynecology, and ${ }^{3}$ Department of Pediatrics, Faculty of Medicine, University of Szeged, Szeged, Hungary
}

\begin{abstract}
Intra-uterine growth retardation (IUGR) is an abnormality of pregnancy. Neonates with IUGR weigh less than the 10th percentile for gestational age. The objective of the study was to identify the relationship between IUGR and the antioxidant status. Cord blood of 157 neonates with normal weight (control group) and 29 neonates with IUGR were included. The following parameters were determined and compared in the two groups: lipid peroxidation in the plasma, red blood cells and erythrocyte ghosts; protein and DNA damage; antioxidant enzyme activities (superoxide dismutase, catalase, glutathione peroxidase); the level of reduced glutathione; and the ferric reducing ability of the plasma. The level of lipid peroxidation was significantly higher in the IUGR group. The antioxidant enzyme activities and the levels of antioxidants were significantly lower in the IUGR group. Damage of proteins and DNA was slightly, but non-significantly, higher in the IUGR group. Neonates with IUGR seem to have significant deficiencies in antioxidant defence. IUGR is correlated with significant oxidative stress.
\end{abstract}

Keywords: Intra-uterine growth retardation, neonates, antioxidant defence

\section{INTRODUCTION}

Intra-uterine growth retardation (IUGR) is a complication of pregnancy, often described as small for gestational age (SGA). A fetus or a newborn with IUGR weighs less than $90 \%$ of all other fetuses or newborns of the same gestational age. The reported incidence of IUGR ranges between $3-10 \%$. IUGR is most probably a consequence of a disorder of the fetomaternal blood circulation. Fetal thrombophilic mutations may lead to placental microthrombosis, which could give rise secondarily to a disturbed fetoplacental blood flow and thus cause growth restriction. ${ }^{1}$ An association has been found between polymorphisms for factor $\mathrm{V}$ Leiden and pro-

Received 28 March 2007

Revised 19 June 2007

Accepted 24 June 2007

Correspondence to: Zsuzsanna Hracsko, Department of Biochemistry and Molecular Biology, University of Szeged, PO Box 533, H 6701

Szeged, Hungary

Tel: +36 62544 543; Fax: +36 62544 877;

E-mail: hracsko@bio.u-szeged.hu thrombin, and asymmetrical intra-uterine growth restriction with immediate unfavourable neonatal outcome. ${ }^{2}$ Leptin takes part in the regulation of fat and also the prenatal fetal weight. A low concentration of leptin can play a role in IUGR. ${ }^{3}$

A fetus with IUGR may be born at term or preterm. This abnormality is associated with increased levels of morbidity and mortality, and deformation of the umbilical cord. IUGR cases with accompanying pathological Doppler findings demonstrate reduction in wall thickness. ${ }^{4}$ Fetuses with a lean umbilical cord are at an increased risk of being small for gestational age. The umbilical cord is defined lean when its cross-sectional area on ultrasound examination is below the 10th percentile for gestational age. ${ }^{5}$

Oxidative stress arises when the balance between oxidants and antioxidants is disturbed. It can occur via an increase in oxygen radical production or decreases in antioxidant enzyme activities. The source of free radicals is the unpaired electron of molecular oxygen, which makes it unstable and electrically charged. In the absence of antioxidant molecules (such as reduced glutathione $[\mathrm{GSH}]$ ) and enzyme activities (e.g. superoxide 
dismutase [SOD], catalase [CAT], and glutathione peroxidase [GPX]), free radicals target lipids, proteins and DNA. Oxidative damage to DNA is a result of interaction of DNA with reactive oxygen species, in particular the hydroxyl radical. Superoxide and hydrogen peroxide are normally not reactive towards DNA. Oxidative attack by hydroxyl radical generates strand breaks on the DNA.

The mechanism of development of IUGR has still not been appropriately described, although it is most probably a consequence of an abnormal fetomaternal blood circulation. Accordingly, we have carried out examinations on umbilical blood in order to establish how the antioxidant status of full-term IUGR infants changes and whether the results indicate significant oxidative stress. We compared the antioxidant status and the level of lipid peroxidation of the umbilical blood in healthy mature neonates and in IUGR neonates.

\section{PATIENTS AND METHODS}

\section{Human study}

The blood samples were obtained from the Department of Obstetrics and Gynecology at the Medical University of Szeged, Hungary. The Ethics Committee of the Department of Obstetrics and Gynecology, Faculty of Medicine, University of Szeged approved the study protocol. A total of 186 full-term mature neonates of either sex, born between weeks 37 and 40 were selected, 157 of them with normal weight $(3450 \pm 550 \mathrm{~g})$ and 29 neonates with symmetrical IUGR (weight $2000 \pm 350 \mathrm{~g}$ ). The $\mathrm{pH}$ of the blood samples was in all cases in the range 7.24-7.39, i.e. there was no hypoxic stress on the tissues. There are several causes of IUGR (genetic disorder, malnutrition, infections, etc.), but in some cases the trigger cause remains unknown. Both the IUGR and the normal cases were free from complications during pregnancy and labour (with the exception of growth disorder in the IUGR group) and there were no pre-eclampsia cases. Neonates were included if their Apgar score after 5 min was 8-10.

Hypoglycaemia that occurred among the IUGR babies was compensated by a $10 \%$ glucose infusion. There were no cases of perinatal asphyxia, congenital anomalies or special morbidities with the exception of hypoglycaemia. The nutritional status of the mothers during pregnancy was satisfactory; no case of malnutrition occurred. The mothers received complete pregnancy care. Smoking mothers and their newborns had a higher concentration of the carbonyl group, lipid peroxides and less total antioxidant capacity. Newborns from these mothers weighed significantly less than others at birth; ${ }^{6}$ consequently, we excluded the smoking mothers.

\section{Biochemical analyses}

Blood was taken from the umbilical vein before the birth of the placenta in both groups. Coagulation was inhibited with heparin. The duration of storage was as short as possible, with a maximum of a week. The blood samples were kept at $-20^{\circ} \mathrm{C}$ until processing. The blood samples were centrifuged at $1000 \mathrm{~g}$ for $10 \mathrm{~min}$ and the plasma and the buffy coat were removed. The red blood cell (RBC) phase was washed twice with 2 volumes of isotonic saline solution at $\mathrm{pH}$ 7.0. The RBCs were haemolysed by the addition of distilled water in a ratio of 1:9. Except for SOD activity determinations, the aliquots of the haemolysates were used directly.

\section{Determination of SOD activity}

Before the determination of SOD activity, haemolysates were treated with ethanol:chloroform $(2: 1)$ to remove haemoglobin from the samples and centrifuged at $3000 \mathrm{~g}^{6}$ The supernatants were used for SOD activity determinations via inhibition of the epinephrine-adrenochrome transformation. ${ }^{7}$ The control sample contained $2.9 \mathrm{ml}$ of $0.05 \mathrm{M}$ carbonate buffer, $\mathrm{pH} 10.2$ (warmed to $37^{\circ} \mathrm{C}$ ) and $0.1 \mathrm{ml}$ of epinephrine $(16.5 \mathrm{mg} / 10 \mathrm{ml} 0.1 \mathrm{~N} \mathrm{HCl})$. The absorbance was measured at $480 \mathrm{~nm}$ for $3 \mathrm{~min}$ after a 1 -min delay. We determined the rate of autoxidation of epinephrine $(\Delta \mathrm{A}$ at $480 \mathrm{~nm} / \mathrm{min}$ ). To measure the inhibition of auto-oxidation by SOD, we used a mixture containing $2.875 \mathrm{ml}$ of the carbonate buffer, $0.025 \mathrm{ml}$ supernatant and $0.1 \mathrm{ml}$ epinephrine. Spectrophotometric measurement was done at $480 \mathrm{~nm}$. The results were expressed in $\mathrm{U} / \mathrm{mg}$ protein.

\section{Determination of CAT activity}

Erythrocyte haemolysates (100-fold dilution) were used. The blank sample was $3 \mathrm{ml}$ of phosphate buffer, $\mathrm{pH} 7.0$, in a quartz cuvette. The incubation mixture contained: 2 $\mathrm{ml}$ of the phosphate buffer (warmed to $37^{\circ} \mathrm{C}$ ), $5 \mu \mathrm{l}$ of haemolysates and $1 \mathrm{ml}$ of $30 \mathrm{mM} \mathrm{H}_{2} \mathrm{O}_{2}$ solution. CAT activity was measured spectrophotometrically at 240 $\mathrm{nm}$. The results were expressed in Bergmeyer units (BU). One $\mathrm{BU}$ is the amount of CAT that decomposes $1000 \mathrm{mg} \mathrm{H}_{2} \mathrm{O}_{2} / \mathrm{min}^{8}{ }^{8}$

\section{Determination of GPX activity}

GPX was also determined spectrophotometrically by using cumene hydroperoxide and GSH as substrates at $412 \mathrm{~nm}$. All samples contained $0.1 \mathrm{ml}$ of haemolysate and $0.7 \mathrm{ml}$ of $0.05 \mathrm{M}$ Tris- $\mathrm{HCl}$ buffer $\mathrm{pH} 7.6$ and were pre-incubated for $10 \mathrm{~min}$ at $37^{\circ} \mathrm{C}$. To the control sample, $0.1 \mathrm{ml}$ of buffered GSH solution was added and the experimental samples were supplemented with both 0.1 $\mathrm{ml}$ of GSH solution and $0.1 \mathrm{ml}$ of buffered $0.05 \%$ cumene hydroperoxide. The samples were then incubated for $10 \mathrm{~min}$ at $37^{\circ} \mathrm{C}$. After $10 \mathrm{~min}, 15 \%$ trichloroacetic acid (TCA) was added to all tubes, and 
$0.1 \mathrm{ml}$ cumene hydroperoxide solution was added to the control tube. The precipitated protein was spun down and $1 \mathrm{ml}$ of supernatant samples was taken for determination of the remaining GSH. They were treated with $2 \mathrm{ml}$ of $0.4 \mathrm{M}$ Tris- $\mathrm{HCl}$ buffer, and 5,5 dithiobis-2-nitrobenzoic acid (DTNB). ${ }^{9}$

\section{Other assays}

The total quantity of protein was determined with the Folin reagent, using bovine serum albumin as standard..$^{10}$

The GSH in the plasma and RBCs was measured using Ellman's reagent (DTNB). Proteins were precipitated with 5\% TCA in order to exclude protein-linked -SH groups from the measurement. ${ }^{11}$

The total antioxidant capacity of the plasma was determined with the FRAP assay, a simple test measuring the ferric reducing ability of plasma, using 2,4,6-tripyridyl$s$-triazine. Ferric to ferrous ion reduction at low $\mathrm{pH}$ causes a coloured ferrous-tripyridyltriazine complex to form. FRAP values are obtained by comparing the absorbance change at $593 \mathrm{~nm}$ in test reaction mixtures with those containing ferrous ions at a known concentration. ${ }^{12}$

\section{Lipid peroxidation assays}

Lipid peroxidation was assayed by two methods. We determined the lipid peroxidation of the plasma and RBCs by using the thiobarbituric acid (TBA) method, which gives the level of total TBA-reactive substances. ${ }^{13}$ Calibration was performed with malonyldialdehyde (MDA). A volume of $2.7 \mathrm{ml}$ of TBA reagent (a mixture of $0.375 \%$ TBA, $0.25 \mathrm{M} \mathrm{HCl}, 15 \%$ TCA) was added to $0.3 \mathrm{ml}$ of the haemolysed blood sample, the components were mixed vigorously and the mixture was heated for $15 \mathrm{~min}$ in a boiling water-bath. Subsequently, the samples were cooled in ice-cold water and centrifuged at $3000 \mathrm{~g}$ for $10 \mathrm{~min}$; the absorbance of the supernatant at
$532 \mathrm{~nm}$ was measured spectrophotometrically to calculate concentrations.

We also measured lipid peroxidation in the RBC membranes by preparing erythrocyte ghosts.

\section{Carbonyl-protein content}

The amount of oxidatively damaged proteins (the carbonyl-protein content) was determined by using 2,4dinitrophenylhydrazine (DNPH). DNA also contains carbonyl groups, so it was removed with $10 \%$ streptomycin-sulphate. Samples were incubated with DNPH at $37^{\circ} \mathrm{C}$. After $1 \mathrm{~h}, 0.5 \mathrm{ml}$ TCA was added and samples were then centrifuged at $3000 \mathrm{~g}$ for $5 \mathrm{~min}$. Pellets were washed three times with ethanol:ethyl-acetate (1:1), resuspended in $2 \mathrm{~N} \mathrm{HCl}(\mathrm{pH} 2.0)$ and incubated at $37^{\circ} \mathrm{C}$ for $15 \mathrm{~min}$. After centrifugation, the absorbance of supernatants was read at $375 \mathrm{~nm}^{14}$

\section{Oxidative DNA damage}

In order to detect oxidative DNA damage, DNA from the whole blood was purified. ${ }^{15}$ The result of the preparation was checked by means of agarose gel electrophoresis and the amount of DNA was determined by measuring the optical density. Oxidative DNA damage was detected by a fluorimetric method. ${ }^{16}$

A Thermo Spectronic Biomate 5 was used for the spectrophotometric measurements. Fluorescence analysis was carried out with dual-channel modulated fluorimeter, emission $590 \mathrm{~nm}$.

\section{Statistical analysis}

Statistical analysis of the data was performed with Student's $t$-test. A $P$-value $<0.05$ was accepted as statistically significant. The Shapiro-Wilks test was applied to confirm the normality of the values. The reported values are mean \pm SD.

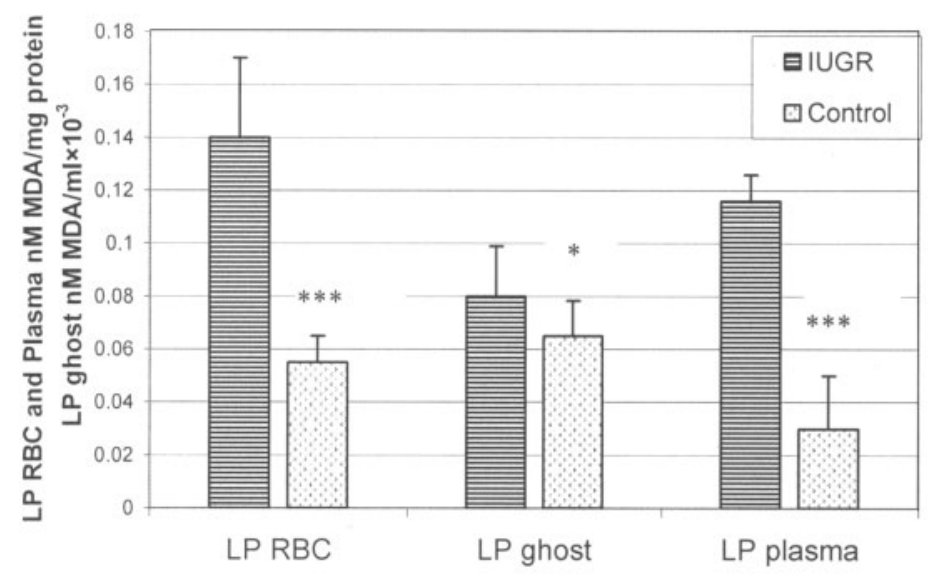

Fig. 1. Lipid peroxidation of red blood cells, plasmas and erythrocyte ghosts in IUGR $(n=29)$ and control $(n=157)$ umbilical blood samples. Values shown to be significantly different from the control data by Student's $t$-test are indicated by an asterisk: $* P<0.05 ; * * P<0.01 ; * * * P<0.001$. 


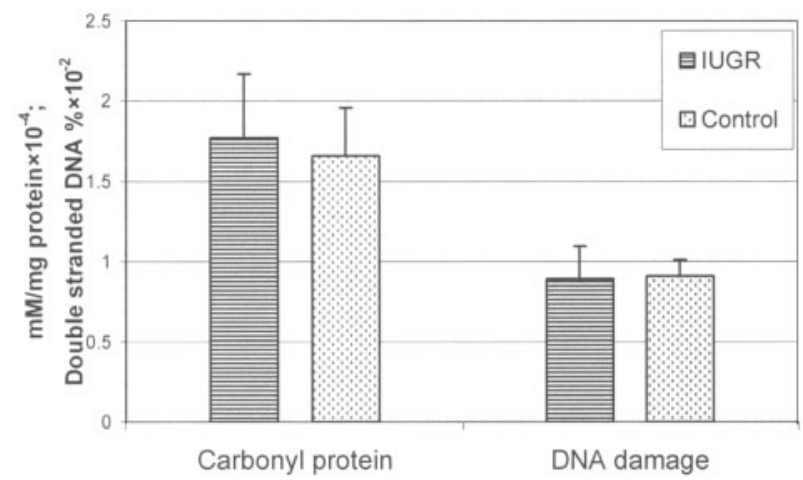

Fig. 2. Protein damage of red blood cells and the DNA damage of whole blood from IUGR $(n=29)$ and control $(n=157)$ umbilical blood samples. The carbonyl protein content is expressed in $\mathrm{mM} / \mathrm{mg}$ protein. The DNA damage is expressed in the percentage of double stranded DNA.

\section{RESULTS}

Figures $1-5$ present the lipid peroxidation and antioxidant activity results on the healthy and IUGR neonates. The levels of lipid peroxidation of the plasma ( 0.116 versus $0.03 \mathrm{nM} \mathrm{MDA} / \mathrm{mg}$ protein), RBCs ( 0.14 versus $0.055 \mathrm{nM} \mathrm{MDA} / \mathrm{mg}$ protein) and the erythrocyte ghosts (0.027 versus $0.018 \mathrm{nM}$ MDA/mg protein) were significantly higher in the IUGR group (Fig. 1). The level of carbonyl protein and DNA damage was slightly, but non-significantly, higher in the IUGR group (1.77 versus $1.66 \mathrm{mM}$ carbonyl-protein/mg protein $\mathrm{x} 10^{-4}$ and $1.75 \%$ more DNA strand breaks in the IUGR group; Fig. 2). The level of GSH (in RBCs, 1.9 versus 6.47; and in plasma, 0.17 versus $1.65 \mu \mathrm{M} / \mathrm{mg}$ protein $\times 10^{-3}$ ) was significantly lower in the IUGR neonates than in the normal group (Fig. 3).

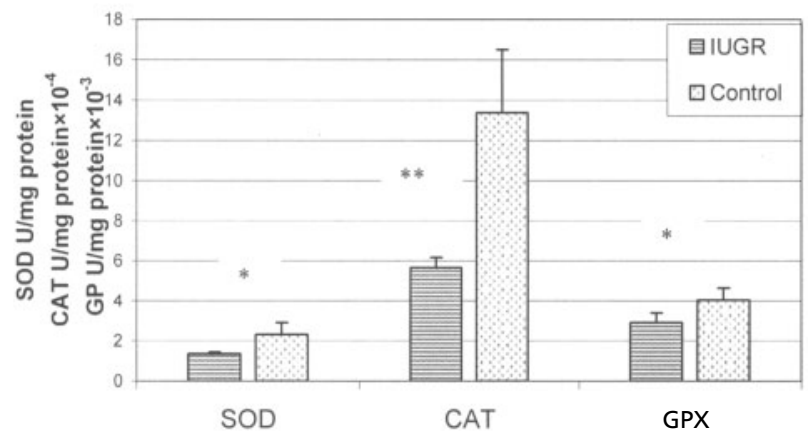

Fig. 4. The activity of superoxide dismutase (SOD), catalase (CAT) and glutathione peroxidase (GPX) in red blood cells of IUGR $(n=29)$ and control $(n=157)$ umbilical blood samples. The antioxidant enzyme activities are expressed in U/mg protein. Values shown to be significantly different from the control data by Student's $t$-test are indicated by an asterisk: $* P<0.05 ; * * P<0.01$.

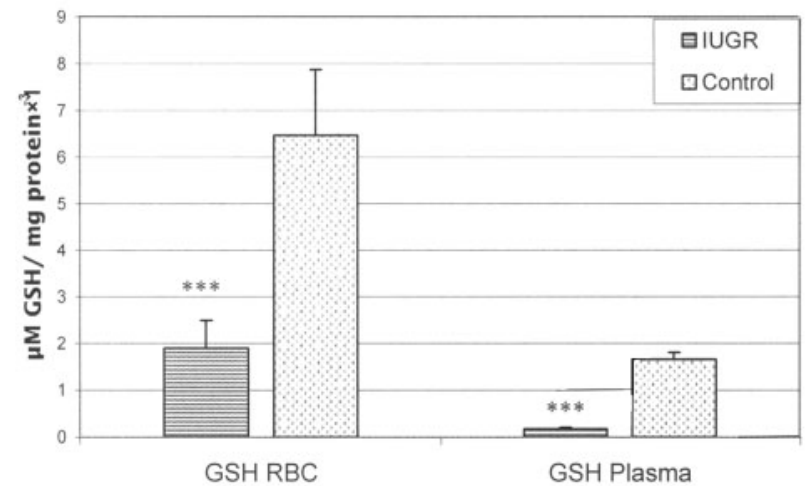

Fig. 3. The level of reduced glutathione (GSH) in plasma and red blood cell of IUGR $(n=29)$ and control $(n=157)$ umbilical blood samples. The concentration of GSH is expressed in $\mu \mathrm{M} / \mathrm{mg}$ protein. Values shown to be significantly different from the control data by Student's $t$-test are indicated by an asterisk: $* * * P<0.001$.

The CAT, SOD and GPX activities (0.565 versus 1.34; 1.35 versus 2.31 ; and 2.9 versus $4.03 \mathrm{U} / \mathrm{mg}$ protein $\times 10^{-3}$ ) in the IUGR group were significantly lower than those in the control group, but there was no significant difference in GPX activities (Fig. 4).

The FRAP (328 versus $289 \mu \mathrm{M})$ was significantly higher in the control group (Fig. 5).

\section{DISCUSSION}

The living organism constantly reacts with oxygen. As a consequence of this activity, highly reactive molecules are produced. These interact with other molecules within the cell, which can cause oxidative damage to proteins, membranes and genes. This damage has been implicated as the cause of certain diseases including neonatal diseases. The antioxidant system defends against free radicals. Under normal conditions, reactive oxygen species

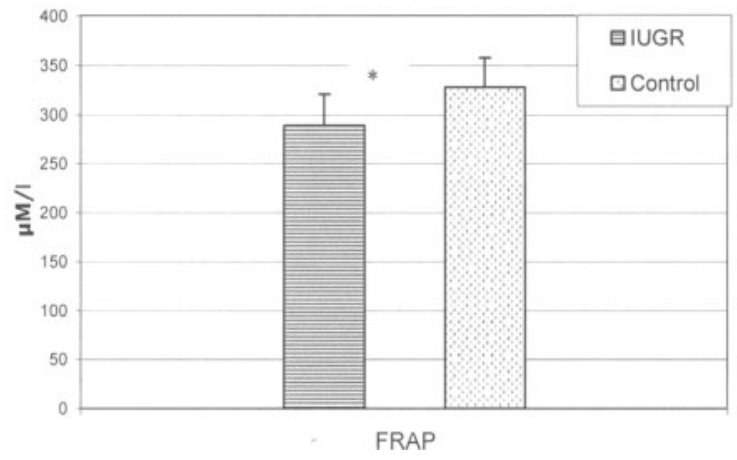

Fig. 5. The ferric reducing ability of plasma (FRAP) from IUGR $(n=29)$ and control $(n=157)$ umbilical blood samples. FRAP is expressed in $\mu \mathrm{M}$. An asterisk indicates values shown to be significantly different from the control data by Student's $t$-test: $* P<0.05$. 
are cleared from the cell by the action of antioxidant molecules and enzymes. Oxidative stress is an imbalance between pro-oxidants and antioxidants, with the former prevailing. The main damage to cells results from the stress-induced alteration of macromolecules such as polyunsaturated fatty acids in membrane lipids, essential proteins, and DNA.

Many neonatal diseases are correlated with oxidative stress. The results of this analysis suggest that the antioxidant defence of neonates with IUGR is similar to that of premature infants as described previously. ${ }^{17} \mathrm{~A}$ recent study states that there is strong evidence of oxidative stress in IUGR babies born to undernourished mothers as evidenced by increased lipid peroxidation and a reduced free oxygen radical scavenger system. ${ }^{18}$ The FRAP and GSH levels and the enzyme activities are too low to defend adequately against oxidative stress. This is why such extensive lipid peroxidation damage can occur. The damage measured on erythrocyte ghosts is an important parameter for the various functions of RBCs. Lipid peroxides may decrease membrane fluidity, inactivate membrane-bound receptors and enzymes, and increase membrane permeability. ${ }^{19}$ The integrity of RBC membranes is crucial for their transfer function. Our results reveal a markedly reduced erythrocyte membrane function in IUGR babies.

A number of studies have suggested a correlation between IUGR and the parameters of oxidative stress. Carbonyl proteins are a consequence of oxidative behaviour. Proteins containing carbonyl groups have an altered structure as compared with intact proteins, which is crucial in view of the relationship between structure and biological activity. A high concentration of carbonyl groups means a high risk of protein destruction. There is a significant difference between the carbonyl group concentrations in normal pregnancies and in IUGR. ${ }^{20}$ We found an increase in the DNA damage of IUGR babies, and other authors confirm this result. ${ }^{21}$

The total antioxidative activity in the blood serum is depressed in pregnancies involving IUGR. After L-arginine treatment the risk of oxidative stress decreased..$^{22}$

In women with IUGR, the processes of lipid peroxidation are enhanced. Colorimetric measurements of lipid peroxides, conjugated dienes, MDA and Schiff bases in women with IUGR reveal the same tendency: the lipid peroxidation is increased, and IUGR is associated with increased membrane damage parameters. ${ }^{23,24}$ This damage is expressed not only in the bloodstream, but also in the nearest tissues. Alterations in the structure of the umbilical cord may be a result of significant oxidative stress. It is more likely that deformation of endothelium is generated by other factors, and apoptosis itself produces free radicals, which induce further cell damage. Oxidative stress can be a consequence of an insufficient antioxidant defence. Maternal infections (cytomegalovirus, toxoplasmosis, etc.), diabetes or substance abuse during pregnancy may also have some effect on oxidative stress.

\section{CONCLUSIONS}

Understanding the role of oxidative stress in the pathophysiology of neonatal diseases is important for designing appropriate prevention strategies and new therapeutic approaches. It is possible to diagnose IUGR during pregnancy by ultrasonography. Adequate antioxidant therapy to compensate the deficiency in the antioxidant defence system may decrease the indices and effects of oxidative stress after confirmation of the findings through intervention studies.

\section{REFERENCES}

1. Schlembach D, Beinder E, Zingsem J, Wunsiedler U, Beckmann MW, Fischer T. Association of maternal and/or fetal factor V Leiden and G20210A prothrombin mutation with HELLP syndrome and intrauterine growth restriction. Clin Sci 2003; 105: 279-285.

2. Verspyck E, Borg JY, Le Cam-Duchez V et al. Thrombophilia and fetal growth restriction. Eur J Obstet Gynecol Reprod Biol 2004; 113: 36-40.

3. Karowicz-Bilinska A. Leptin concentration in women with normal pregnancy and intrauterine growth retardation. Ginekol Pol 2004; 75: 10-14.

4. Bruch JF, Sibony O, Benali K, Challier JC, Blot P, Nessmann C. Computerized microscope morphometry of umbilical vessels from pregnancies with intrauterine growth retardation and abnormal artery. Doppler Hum Pathol 1997; 10: 1139-1145.

5. Raio L, Ghezzi F, Di Naro E et al. Prenatal diagnosis of a lean umbilical cord: a simple marker for the fetus at risk of being small for gestational age. Ultrasound Obstet Gynecol 1999; 13: 176-180.

6. Arguelles S, Machado MJ, Ayala A, Machado A, Hervias B. Correlation between circulating biomarkers of oxidative stress of maternal and umbilical cord blood at birth. Free Radic Res 2006; 40: 565-570.

7. Misra HP, Fridovich I. A role of superoxide anion in the autoxidation of epinephrine and a simple assay for superoxide dismutase. J Biol Chem 1972; 247: 3170-3175.

8. Beers Jr RF, Sizer IW. Spectrophotometric method for measuring the breakdown of hydrogen peroxide by catalase. J Biol Chem 1952; 195: 133-140.

9. Chiu DT, Stults FH, Tappel AL. Purification and properties of rat lung soluble glutathione peroxidase. Biochim Biophys Acta 1976; 445: $558-566$.

10. Lowry OH, Rosebrough EA, Farr AL, Randall RJ. Protein measurement with Folin phenol reagent. J Biol Chem 1951; 193 : 265-275.

11. Sedlak J, Lindsay RH. Estimation of total protein-bound and nonprotein sulfhydryl groups in tissue with Ellman's reagent. Anal Biochem 1968; 25: 192-205.

12. Benzie FF, Strain JJ. The ferric reducing ability of plasma (FRAP) as a measure of 'antioxidant power': the FRAP assay. $J$ Biol Chem 1996; 239: 70-76.

13. Placer ZA, Cushman L, Johnson SC. Estimation of product of lipid peroxidation (malonyl dialdehyde) in biochemical systems. 
16 Hracsko, Orvos, Novak, Pal, Varga

Anal Biochem 1966; 16: 359-364.

14. Levine RL, Garland D, Oliver CN et al. Determination of carbonyl content in oxidatively modified proteins. Methods Enzymol 1996; 186: 464-478.

15. Wang L, Hirayasu K, Ishizawa M, Kobayashi Y. Purification of genomic DNA from human whole blood by isopropanolfractionation with concentrated NaI and SDS. Nucleic Acid Res 1994; 22: 1774-1775.

16. Birnboim HC, Jevcak JJ. Fluorimetric method for rapid detection of DNA strand breaks in human white blood cells produced by low doses of radiation. Cancer Res 1981; 41: 1889-1892.

17. Varga SI, Matkovics B, Pataki L, Molnar A, Novak Z. Comparison of antioxidant red blood cell enzymes in premature and full-term neonates. Clin Chim Acta 1985; 147: 191-195.

18. Gupta P, Narang M, Banerjee BD, Basu S. Oxidative stress in term for gestational age neonates born to undernourished mothers: a case control study. BMC Pediatr 2004; 4: 14

19. Fogel I, Pinchuk I, Kupferminc MJ, Lichtenberg D, Fainaru O.
Oxidative stress in the fetal circulation does not depend on the mode of delivery. Am J Obstet Gynecol 2005; 193: 241-246.

20. Karowicz-Bilinska A, Marszalek M, Kowalska-Koprek U, Suzin $\mathrm{J}$, Sieroszewski P. Plasma carbonyl group concentration in pregnant women with IUGR treated by L-arginine and acetylsalicylic acid. Ginekol Pol 2004; 75: 15-20.

21. Takagi Y, Nikaido T, Toki T et al. Levels of oxidative stress and redox-related molecules in the placenta in preeclampsia and fetal growth restriction. Virchows Arch 2004; 444: 49-55.

22. Karowicz-Bilinska A, Kowalska-Koprek U, Suzin J, Sieroszewski P. Total antioxidative activity measured by ABTS method in pregnant women treated with L-arginine for IUGR. Ginekol Pol 2003; 74: 1130-1136.

23. Karowicz-Bilinska A. Lipid peroxide concentrations in women with intrauterine growth restriction. Ginekol Pol 2004; 75: 6-9.

24. Karowicz-Bilinska A, Suzin J, Sieroszewski P. Evaluation of oxidative stress indices during treatment in pregnant women with intrauterine growth retardation. Med Sci Monit 2002; 8: 211-216. 